\title{
The Chinese notional Passive Construction under the View of Cognitive Construction Grammar
}

\author{
Liulin ZHANG \\ Truman State University, USA \\ liulinz@truman.edu
}

\begin{abstract}
The notional passive construction (NPC, henceforth) is claimed to be the most common form of passive and the earliest mode of passive expression in Chinese. However, under the view of cognitive construction grammar, NPC remains a mystery with its form not clearly defined and its function not particularly discussed. Taking a character-based historical approach, this paper studies the form designated by NPC, that is the 'theme + verbal phrase' structure on corpus data. Results show that the 'theme + verbal phrase' structure has been extremely stable in the history of the Chinese language, denoting change of state. In conjunction with some cross-linguistic findings, a change-ofstate construction can thereby be proposed for the form 'theme + verbal phrase'. Accordingly, the idea of the so-called "notional passive construction" is challenged in the way that it essentially refers to a special situation of the change-of-state construction when the event expressed by the verbal phrase is not likely to occur spontaneously- it is not a construction itself, yet plausibly passive.
\end{abstract}

Keywords: Chinese; the notional passive construction; change of state; cognitive construction grammar

\section{Povzetek}

Namišljena oblika trpnika (notional passive construction, NPC) je poznana kot najpojavnejša oblika trpnika in tudi kot najzgodnejši način izražanja trpnika v kitajščini. Ne glede na to pa $v$ kognitivni konstrukcijski slovnici ostaja pod velikim vprašajem, saj je njena struktura nejasna in njena vloga slabo raziskana. Članek s pomočjo korpusa obravnava namišljeno obliko trpnika, tj. strukturo tema + glagolska fraza in sicer po tradicionalni metodi, ki postavlja znak kot osnovo. Rezultati raziskave kažejo, da je bila omenjena slovnična struktura v kitajskem jeziku vedno zelo stabilna ter da izraža spremembo stanja. $\vee$ navezavi na že obstoječe raziskave o drugih jezikih tako predlagamo ustreznik strukturi tema + glagolska fraza ustreza ideji spremembe stanja. S tem se porajajo pomisleki o obstoju namišljene oblike trpnika, saj se le-ta povečini nanaša na posebne primere sprememb stanja, ko pojavnost dejanja, izraženega z glagolsko frazo, ni spontana. Ravno zato je težko reči, da je to oblika trpnika, čeprav to najverjetneje je.

Ključne besede: kitajščina; fiktivni trpnik; sprememba stanja; kognitivna konstrukcijska slovnica

Acta Linguistica Asiatica, 8(2), 2018.

ISSN: 2232-3317, http://revije.ff.uni-lj.si/ala/

DOI: 10.4312/ala.8.2.83-110 


\section{Introduction}

In Chinese, the commonly recognized passive markers include 被 bei, 叫 jiao, and 让 rang. It has also been noticed that unlike English, where most transitive active clauses can be turned into a passive form (Wang, 1958/2004), in Mandarin Chinese the 被 bei/ 叫 jiao/让 rang passive is not a productive construction, as it is only available with certain verbs and in limited environments. Keenan (1985) pointed out that Mandarin Chinese is relatively low on the scale of productivity of marked passive, although it is not at the bottom, as there are languages (e.g., Chadic languages and many languages in New Guinea) do not allow passive at all.

McEnery \& Xiao (2010, p. 85) studied a parallel corpus composed of 250,000 English words and over 400,000 Chinese words, and found that only about $20 \%$ of be passives are translated into Chinese using syntactically marked passive constructions, with the majority being translated using so-called notional passives, subjectless sentences, sentences with vague subjects (e.g., 有人 youren 'someone', 人们 renmen 'people', 大家 dajia 'all'), and special sentences (e.g., the disposal 把 ba construction and the predicative 是...的 shi ... de structure). Researchers have also noticed some

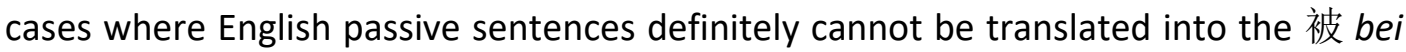
construction. For example:

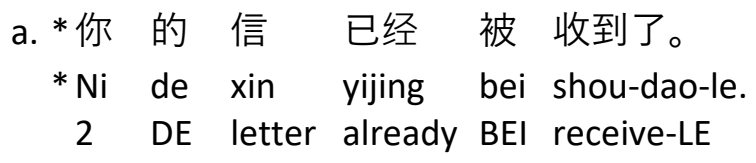

$$
\begin{aligned}
& \text { b. 你 的信 已经 收到了。 } \\
& \mathrm{Ni} \text { de xin yijing shou-dao-le. } \\
& 2 \text { DE letter already receive- LE } \\
& \text { 'Your letter has already been received.' }
\end{aligned}
$$

(from Cheung, Liu, \& Shih, 1994, p. 494)

$$
\begin{aligned}
& \text { (33) a. *饭 被 烧好了。 } \\
& \text { *Fan bei shao-hao-le. } \\
& \text { meal BEl cook-ready-LE }
\end{aligned}
$$

b. 饭烧好了。

Fan shao-hao-le.

meal cook-ready-LE

'The meal is ready.'

(from Zhou \& Jin, 2004, p. 61)

Researchers claim that the notional passive construction (NPC, henceforth, sometimes also referred to as the unmarked passive construction or the pseudopassive construction) as shown in (1b) and (2b) is "the most common form of passive in Chinese" (Yip \& Don, 2004, p. 210) and the earliest mode of passive expression in Chinese (Wang, 1957, 1958/2004, p. 418). 
Despite the literature discussing the constraints of NPC (e.g., C. Wang, 1998; Z. Wang, 2004) and the derivation of it (e.g., Cheng \& Huang, 1994; Li, 1994; Li \& Thompson, 1981, p. 85; Ting, 2006), NPC is yet to be clearly defined in language use, especially regarding its distinction from the so-called inchoative/unaccusative/ ergative/anticausative structure. Among the following examples, it is still open to question whether they can be treated as NPC.

(34) 物 以 类聚。

Wu yi lei ju.

thing by category accumulate

'Things accumulate by category.'

(35) 电影完了。

Dianying wan-le.

movie finish-LE

'The movie finished.'

(36) 门开了。

Men kai-le.

door open-LE

'The door opened./ The door is open.'

(37) 蛋糕吃了。

Dangao chi-le.

cake eat-LE

'The cake is eaten.'

The confusion regarding the definition of NPC motivated this study.

\section{Framework and Methodologies}

\subsection{Cognitive construction grammar and its basic tenets}

Set within the framework of cognitive construction grammar (Goldberg, 1995, 2003, 2006; Langacker, 2008), this study assumes that language is usage-based, and grammatical constructions are the fundamental building blocks of language. In this view, all levels of grammatical analysis involve constructions: learned pairings of form with semantic or discourse function, including morphemes or words, idioms, partially filled and fully lexical patterns (Boas, 2013). The architecture of a construction, coupling a particular form with a specific (conventional) meaning, is illustrated as follows: 


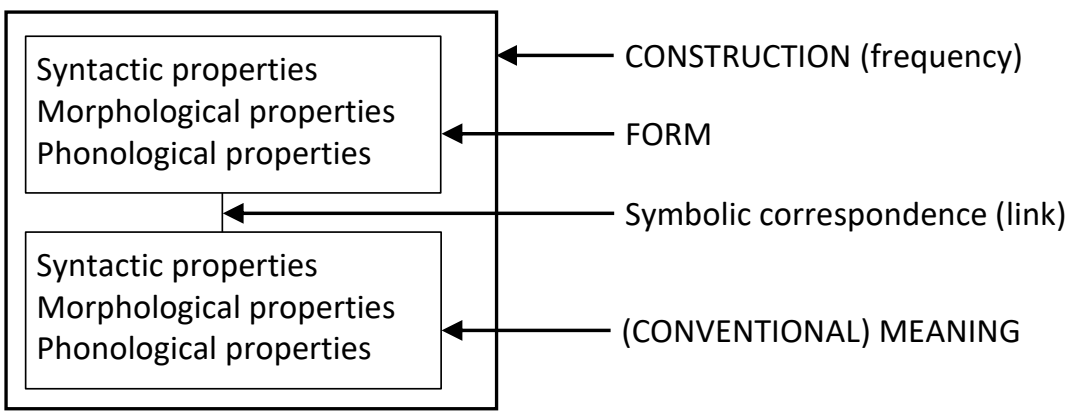

Figure 1: The symbolic structure of a construction (Croft, 2001, p.18)

According to Goldberg (1995, p. 4, 2003, 2006, p. 6), whenever some aspects of a form-function pair is not fully predictable from its components or from other previously established constructions, it may become necessary to propose another construction. Correspondingly, a "what you see is what you get" approach to syntactic form is adopted, which means no underlying levels of syntax or any phonologically empty elements are posited.

In addition, cognitive construction grammar attaches special importance to the relationship between human language and cognition, as Tyler $(2012$, p. 28) puts it, "language is best understood as a reflection of humans' multiple, dynamic, interacting cognitive processes and cognitive structures". Assuming that language describes our experiences of the world, linguistic constructions (corresponding to basic sentence types) encode as their prototypical senses event types that are basic to human experience - those of something moving, something being in a state, someone causing a change of possession, something undergoing a change of state or location, something having an effect on someone, etc. (cf. Croft, 2001, 2012; Ellis et al., 2015; Goldberg, 1995; Levin, 1993). Such events are conceptualized by human mind, and experimentally grounded gestalts are thus formed, which further constitute the conceptual schemas of linguistic constructions.

In sharp contrast to formal linguistics, cognitive construction grammar maintains that language is usage-based instead of rule-generated: We learn linguistic constructions while engaging in communication (Bybee, 2010), and contextualized exposure to input and frequency has an effect on language learning, processing, and novel use of language (Langacker, 1988; Bybee, 2012). Therefore, this study will not rely on discrete examples (which is typically the approach adopted by previous studies) to talk about NPC. Instead, a bottom-up corpus-based approach will be employed. Discussion will be built upon statistical analysis of corpus data.

To my knowledge, with the hierarchical structures of syntax abandoned, NPC remains a mystery under the view of cognitive construction grammar, with its form not 
clearly defined in language use and its function not particularly discussed albeit assumed as "passive".

\subsection{Methodologies}

Although a distinct construction is defined to exist as long as some of its form or function is not strictly predictable from its components, this does not necessarily mean that functions of different levels of constructions are mutually independent of each other. Constructionists note that at least verb meanings interact with abstract argument structure constructions in non-trivial ways (cf. Goldberg, 2003). For example, there are always some verbs closely associated to a particular construction (e.g., give is highly indicative of the ditransitive construction, whereas leave, although it can form a ditransitive, occurs in other constructions more frequently) (Ellis et al., 2015). The proportion of tokens of total verb usage that appear in this particular construction is called "faithfulness" (e.g., the faithfulness of give to the ditransitive is approximately 0.40; that of leave is 0.01 ), and is taken as one measure of verb-construction contingency (Ellis et al., 2011). It has been shown that semantically prototypic verbs are "pathbreakers" in that they seed the growth of verb-argument constructions (cf. Goldberg et al., 2004; Ninio, 1999), and they also appear to be the most faithful to those constructions in corpus data (e.g., Ellis \& Cadierno, 2009; Ellis et al., 2014). In light of these theories, this paper approaches NPC by investigating the semantic prototypes of the verbs therein, and quantifying the verb-construction contingency through faithfulness.

In an attempt to apply cognitive construction grammar to the study of Chinese, a character-based diachronic approach is employed. Despite the fact that synchronic analysis had become the mainstream of linguistics ever since Saussure's Course in General Linguistics (1916/1959, pp. 25-26), the importance of diachronic study is reestablished by cognitive construction with the assumption that structures emerge from use (cf. Langacker, 1987). Applied to Chinese, the diachronic approach essentially has to be accompanied by the character-based approach because Chinese has been documented in characters and there is technically no way to know for sure how characters are pronounced in a particular period of time. For example, some historical linguists posit phonetic contrast of verbs in Old Chinese when used transitively versus intransitively (e.g., Mei, 1991; Yu, 1984). However, with no systematic rules but only a conjecture drawn on a very limited number of discrete examples, this paper will stick to the characters without considering the possibility of phonetic contrast.

Applying the character-based diachronic approach to corpus, a problem arises as to how to identify NPC since it is not marked and its form is not clearly defined. In this paper, all possible tokens of NPC, which take the form of 'theme + verbal', will be analyzed in the initial step. To make sure there is a corresponding 'active' construction to the passive construction, the verbals in the collected tokens must be used 
transitively at least once in that historical period. The 'theme + verbal' structures, with the transitive use of the verbal confirmed in corpus, will be referred to as TVS thereafter, to distinguish from NPC.

Analysis starts with a relatively small corpus comprising of some literary works with the intention of exhaustively finding all tokens of TVS, and verbs that frequently occur in TVS can thereby be singled out, with the semantic prototypes instantiated by them further identified. Literary works selected to form the small corpus of each historical period are shown below:

Table 1: Literary works selected for small corpora of different historical periods

\begin{tabular}{|c|c|c|}
\hline Historical period & Selected literal works & $\begin{array}{r}\text { Character } \\
\text { Count }\end{array}$ \\
\hline $\begin{array}{l}\text { The pre-Qin period } \\
\text { (Old Chinese) }\end{array}$ & 《孟子》 'Mencius' & 38,125 \\
\hline
\end{tabular}

The Tang dynasty Ten Chuanqi stories (i.e. 《任氏传》'The Story of Ren',

(Middle Chinese) 《南柯太守传》'The Story of the Governor of Nanke', 《李娃传》'The Story of Li Wa', 《枕中记》'Record within a Pillow', 《柳毅传》'The Story of Liu Yi'，《柳氏 传》'The Story of Liu', 《聂隐娘传》'The Story of Nie Yinniang'，《蒀莺传》'The Story of Yingying', 《虬髯客 传》'The Legend of the Curly-whiskered Guest', and 《霍 小玉传》 'The Story of Huo Xiaoyu')

The Ming dynasty Four Sanyan stories (i.e. 《蒋兴哥重会珍珠衫》'Jiang 69,139 (Early Mandarin) Xingge Reencounters His Pearl Shirt”，《杜十娘怒沉百宝 箱》 'Du Shiniang Sinks Her Jewel Box in Anger'，《卖油郎 独占花鬼》' 'The Oil-Peddler Wins the Queen of Flowers', and 《施润泽滩阙遇友》'Shi Fu Encounters a Friend at Tanque')

Modern Mandarin Wang Shuo's novel 《过把瘾就死》 'Die Satisfied' 59,212

Then, a few target verbs are picked that are diverse and relatively stable in verbal semantics, not too polysemous and do not have homonyms. The faithfulness of the selected target verbs to TVS in all available texts of that historical period are quantified. The corpus I am using is Cncorpus (语料库在线 Yuliaoku Zaixian), administered by the State Language Work Committee of P. R. China (国家语言文字工作委员会 Guojia Yuyan Wenzi Gongzuo Weiyuanhui). 


\section{Semantic Prototypes of the Predicates in TVS}

\subsection{TVS in Old Chinese}

According to Wang (1958/2004, p. 35), features of Old Chinese include: (1) scarce copular use in judging sentences; (2) pronominal objects in questions and negative sentences placed before the verb. As a deterministic distinction from Middle Chinese, the 被 bei construction, the particle 了 $l e$ and 着 zhe have not been fully grammaticalized in Old Chinese. In Old Chinese, about $80 \%$ of words are monosyllabic (Baxter \& Sagart, 1998).

With special sentence patterns (e.g., questions/negative sentences with pronominal objects, structures containing 可 $k e$ 'can'/足 zu 'suffice'/难 nan 'be difficult to', etc.) excluded, for Old Chinese, 37 tokens of TVS are collected from Mencius, and the subjects are inanimate in 20 of them (54.05\%). 29 of the tokens are positive sentences, seven negative sentences, and one question. The type frequencies of the verbs in these 37 tokens are aggregately shown in Table 2 .

Table 2: Type frequencies of the verbs in TVS in Mencius

\begin{tabular}{|c|c|c|c|c|c|}
\hline Verb & Meaning & Frequency & Verb & Meaning & Frequency \\
\hline 举 & raise & 5 & 亡 & die & 1 \\
\hline 见 & appear/see & 3 & 备 & prepare & 1 \\
\hline 闻 & hear & 3 & 斌 & slay (the King) & 1 \\
\hline 卒 & die & 3 & 聚 & accumulate & 1 \\
\hline 行 & implement & 2 & 蔽 & cover & 1 \\
\hline 听 & listen & 2 & 助 & help & 1 \\
\hline 定 & pacify & 2 & 驾 & harness & 1 \\
\hline 辟 & avoid & 2 & 削 & cut down & 1 \\
\hline 用 & use & 1 & 税 & $\operatorname{tax}$ & 1 \\
\hline 成 & complete & 1 & 溢 & overflow & 1 \\
\hline 食 & eat & 1 & 絜 & (used as 洁) clean & 1 \\
\hline 治 & govern & 1 & Total & & 37 \\
\hline
\end{tabular}

Note. All the meanings for verbs displayed in this table are the meanings in the contexts of the collected tokens, same below.

Some TVS tokens of Old Chinese are as follows, with the verbs bolded:

(38) 牲杀器血、衣服不备, 不敢以祭。 Sheng sha qimin yifu bu bei bu gan yi ji. victims for slaughter vessel garment NEG prepare NEG dare to sacrifice 'The victims for slaughter, the vessels, and the garments, not being all complete, he does not presume to sacrifice.' 
(39) 耳 目之官不思, 而蔽于物。

Er mu zhi guan bu si, er bi yu wu.

ear eye ZHI rgan NEG think CONJ cover by thing

'The organs of ears and eyes do not think but covered by things.'

(40) 棟 行 言 听, 亳泽下 于 民。 Jian xing yan ting, gao ze xia yu min. admonishment implement suggestion listen benefit down to people 'If admonishments can be implemented and suggestions can be listened to, the benefit will be able to go down to people.'

Besides, adverbs indicating perfective are observed from three tokens:
(41)
牺牲 既 成
成, 㴽
盛
既 絜。
Xi sheng ji
cheng zi
cheng
ji
jie.
sacrifice already complete rice grains (in the vessel) already clean

'The sacrifice is ready. The rice and the grains have already been cleaned in the vessel.'

(42)

$\begin{array}{llllll}\text { 今 } & \text { 乘 } & \text { 與 } & 己 & \text { 驾 } & \text { 矣。 } \\ \text { Jin cheng } & \text { yu } & \text { yi } & \text { jia } & \text { yi. } \\ \text { now } & \text { horse } & \text { carriage } & \text { already } & \text { harness } & \text { SFP }\end{array}$

'The horse and carriage have already been harnessed (are ready now).'

\subsection{TVS in Middle Chinese}

The following characteristics distinguish Middle Chinese from Old Chinese (Wang, 1958/2004, p. 35): (1) mandatory copulars in judging sentences; (2) the emergence of the disposal structure; (3) frequent use of the 被 bei construction; (4) the emergence of the aspect particles 了 le and 着 zhe.

When it comes to the corpus analysis, 214 tokens of TVS, formed by 114 verbs, are collected from ten Chuanqi stories, with special sentence patterns excluded. Among 214 tokens, themes are inanimate in 135 tokens (63.08\%), animate in 79 tokens (36.92\%). Positive sentences account for 154 tokens (71.96\%), 52 are negative sentences $(24.30 \%)$, and the rest are questions or double negative sentences. 41 verbs occur more than once in the collected tokens. Their frequencies are listed in Table 3.

Table 3: Type frequencies of the verbs in TVS in Chuanqi stories

\begin{tabular}{llc}
\hline Verb & Meaning & Frequency \\
\hline 断 & cut off & 5 \\
讫 & complete & 4 \\
举 & raise & 3 \\
发 & let off & 3 \\
授 & confer & 3 \\
毕 & finish & 3 \\
\hline
\end{tabular}

\begin{tabular}{llc}
\hline Verb & Meaning & Frequency \\
\hline 爱 & love & 3 \\
生 & appear & 3 \\
立 & establish & 3 \\
终 & complete & 3 \\
聚 & accumulate & 3 \\
解 & untie & 3 \\
\hline
\end{tabular}




\begin{tabular}{llc}
\hline Verb & Meaning & Frequency \\
\hline 转 & transfer & 3 \\
迁 & move & 3 \\
通 & dredge & 3 \\
闻 & hear & 3 \\
下 & down & 2 \\
买 & buy & 2 \\
以 & use & 2 \\
保 & protect & 2 \\
动 & break out & 2 \\
化 & turn; change & 2 \\
合 & unite & 2 \\
定 & pacify & 2 \\
尽 & finish & 2 \\
居 & live & 2 \\
彰 & cite & 2 \\
\hline
\end{tabular}

\begin{tabular}{llc}
\hline Verb & Meaning & Frequency \\
\hline 得 & get & 2 \\
忘 & forget & 2 \\
持 & hold & 2 \\
攀 & draw & 2 \\
数 & count & 2 \\
激 & surge & 2 \\
税 & rent, buy & 2 \\
给 & give & 2 \\
绝 & cut off & 2 \\
署 & dispose & 2 \\
胜 & can bear & 2 \\
谪 & exile & 2 \\
载 & record & 2 \\
销 & melt & 2 \\
\hline Total & & 101 \\
\hline
\end{tabular}

Some TVS tokens of Middle Chinese are as follows, with the verbs bolded:
(43) 幽会
未 终, 惊
魂已
断。
You hui
wei zhong, jing
hun yi
duan.

secret meeting not finish frightened spirit already cut off

'Even before the secret meeting (with my lover) finishes, my frightened feeling has already been cut off.'

(《莺莺传》)

(44) 信 问 不 绝。
Xin wen bu jue.
letter greeting NEG finish
'Letters and greetings never end.'

(《南柯太守传》)

(46) 有一仙人, 谪 在下界。

You yi xianren, zhe zai xiajie.

TOP one immortal exile at the world of man

'There is an immortal exiled at the world of man.' 
In parallel with the continuous disyllabification of the Chinese language, disyllabic elements began to be found in the verb position, including 流连 liulian 'linger', 温习 wenxi 'review' and 罗列 luolie 'arrange for show'. In addition, 已 Yi 'already', an adverb indicating perfective, occurs before the verb in six tokens.

\subsection{TVS in Early Mandarin}

Early Mandarin is primarily defined by phonetic features such as the disappearance of the entering tone (入声 rusheng), and disappearance of the three-way contrast between voiceless unaspirated, voiceless aspirated and voiced consonants of the initial stops and affricates (Wang, 1958/2004, p. 35). In terms of vocabulary and grammar, Early Mandarin inherited and promoted the traits developed by Middle Chinese. More disyllabic words are observed, and the disposal structure, the 被 bei construction, and the particles 了 le and 着 zhe become more commonly used.

With special sentence patterns (e.g., questions/negative sentences with pronominal objects, the 被 bei construction, etc.) excluded, 618 tokens of TVS are collected from four Sanyan stories. Compound verbals ${ }^{1}$ occur in 292 tokens. As for those TVS tokens structured around monosyllabic verbs, inanimate themes occur in 254 tokens (77.91\%), and 238 tokens (73.00\%) are positive sentences. 171 monosyllabic verbs are seen in these tokens, with 57 of them occurring in more than one token, as presented in Table 4.

Table 4: Type frequencies of monosyllabic verbs in TVS in Sanyan stories

\begin{tabular}{|c|c|c|c|c|c|}
\hline Verb & Meaning & Frequency & Verb & Meaning & Frequency \\
\hline 成 & accomplish & 10 & 开 & open & 5 \\
\hline 来 & come & 10 & 有 & have & 5 \\
\hline 落 & fall & 10 & 动 & touch & 4 \\
\hline 去 & go & 10 & 合 & converge & 4 \\
\hline 罢 & finish & 9 & 生 & subsist & 4 \\
\hline 绝 & cut off & 9 & 会 & meet; know & 3 \\
\hline 尽 & finish & 7 & 报 & recompense & 3 \\
\hline 毕 & finish & 7 & 备 & prepare & 3 \\
\hline 说 & say & 6 & 出 & go out & 3 \\
\hline 吃 & eat; drink & 5 & 断 & cut off & 3 \\
\hline 发 & let off & 5 & 集 & gather & 3 \\
\hline 见 & see & 5 & 了 & end & 3 \\
\hline 接 & pick up & 5 & 起 & start & 3 \\
\hline
\end{tabular}

\footnotetext{
${ }^{1}$ The term 'compound verbal' is used in this paper to refer to both compound verbs and verb compounds. Because language is assumed to be usage-based, there is no clear-cut border between syntactic patterns and words. The difference between compound verbs and verb compounds is understood to lie mainly in frequency.
} 


\begin{tabular}{llc}
\hline Verb & Meaning & Frequency \\
\hline 失 & lose & 3 \\
要 & want & 3 \\
止 & stop & 3 \\
至 & arrive & 3 \\
坐 & sit & 3 \\
与 & give & 3 \\
过 & pass & 2 \\
从 & follow & 2 \\
闭 & close & 2 \\
荡 & swing & 2 \\
到 & arrive & 2 \\
定 & pacify & 2 \\
飞 & fly & 2 \\
空 & empty & 2 \\
卖 & sell & 2 \\
迷 & infatuate & 2 \\
\hline
\end{tabular}

\begin{tabular}{llc}
\hline Verb & Meaning & Frequency \\
\hline 明 & light & 2 \\
暖 & warm & 2 \\
认 & recognize & 2 \\
舍 & abandon & 2 \\
同 & same & 2 \\
忘 & forget & 2 \\
下 & fall & 2 \\
想 & think & 2 \\
醒 & awake & 2 \\
虚 & empty & 2 \\
许 & approve & 2 \\
愈 & recover & 2 \\
葬 & bury & 2 \\
沾 & touch (water) & 2 \\
醉 & drunk & 2 \\
\hline Total & & 212 \\
\hline
\end{tabular}

TVS tokens of Early Mandarin structured around monosyllabic verbs are exemplified below:
(47) 一 块 鳖鱼
Yi kuai bieyu
落 地。
one piece soft-shelled turtle fall ground
'A piece of soft-shelled turtle fell onto the ground.'

（《卖油郎独占花鬼》）

$\begin{array}{llllll}\text { (48) 十四岁 谓 之 开花, 此时 天癸 } & \text { 已 } & \text { 至。 } \\ \text { Shisi sui wei zhi kai hua, ci shi tiangui } & \text { yi } & \text { zhi. }\end{array}$ 14 years' old call 3 open flower this time Tiangui (period) already arrive 'Fourteen is called bloom. Period has already arrived at this time.'

(《卖油郎独占花鬼斗》)

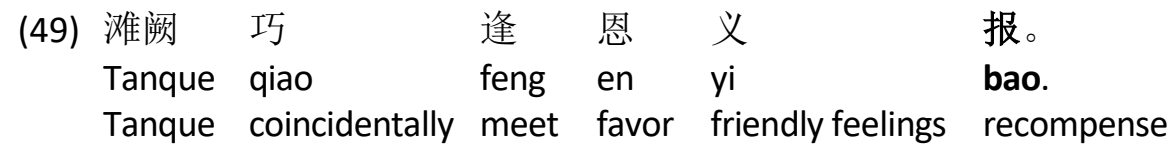

'All favor and friendly feelings were recompensed in the coincident meeting at

Tanque.'

(《施润泽滩阙遇友》)

In terms of the 292 tokens with compound verbals as the predicates, if we represent the structure of the predicates as ' $X Y^{\prime}$ ', the elements in the $\mathrm{X}$ position are various in verbal semantics, and the most frequent elements in the $Y$ positon include 得 de ' get' $^{\prime}$ (seen in ten tokens), 来 lai 'come' (nine tokens), 成 cheng 'accomplish' (eight tokens), 去 qu 'go' 
(eight tokens), 下 xia 'go down' (eight tokens), 出 chu 'exit' (seven tokens), 尽 jin 'finish' (five tokens) and 完 wan 'finish' (four tokens). Examples are as follows:

(50) 那边 还放下许多 客账, 不 曾 取得。 Na bian hai fang-xia xuduo ke zhang bu ceng qu-de. that sidestill put-down many customer account NEG yet get-get 'There are still many customer account loans there that have not been paid back.'

(《施润泽滩阙遇友》)

(51) 方才 箱子 可 暂发来。

Fangcai xiangzi ke zan fa-lai.

just now suitcase can for now send-come

'The suitcase that you saw before can be sent here for now.'

(《杜十娘怒称百宝箱》)

(52) 美娘十二岁 到王家, 锦绣中 养成。

Meiniang shi'er sui dao Wang jia, jinxiu - zhong yang-cheng.

Meiniang 12 years get to House Wang, brocade -in cultivate-accomplish 'Meiniang came to the House of Wang at the at the age of 12, and was raised up in beautiful brocade.'

(《卖油郎独占花鬼》)

The verbals co-occur with 了 le, 过 guo, or 已yi in 70 tokens, expressing a perfective aspect, as in the following examples:

(53) 当下 三 杯 两 戞, 吃了一回。 Dangxia san bei liang zhan, chi-le yi hui. that point three cup two cup eat-LE one time 'At that point, (they) drank some cups of wine.'

\section{(《施润泽滩阙遇友》)}

(54) 身边 藏下 些 散碎 银两, 都 用尽了。 Shenbian cang-xia xie sansui yinliang, dou yong-jin-le. by one's side save some piecemeal money all use-finish-LE 'As for the piecemeal money that have been saved by his side, it is all used up.'

(《卖油郎独占花鬼》)

\subsection{TVS in Modern Mandarin}

With the continuous process of disyllabification, the proportion of disyllabic words is reported to be $62.79 \%$ and $75.18 \%$ in Modern Chinese Dictionary (《现代汉语词典》) and Chinese New Word Dictionary (《汉语新词词典》) respectively (cf. Xu, 1997). In terms of the grammar of Modern Mandarin, because of the self-conscious Europeanization of scholars, Modern Mandarin internalized some Indo-European grammatical features (Wang, 1958/2004, p. 35), instantiated by the systematic use of subjects, pronouns and copulas, the increased length of Chinese sentences, especially 
in the modifiers, the expansion of the function of BEIC, the Europeanization of coordination strategy of nouns, the emergence of indefinite articles, and so forth.

In my corpus analysis, a sample of 614 tokens of TVS was collected from Wang Shuo's novel Die Satisfied (《过把瘾就死》). 237 tokens (38.60\%) therein start with animate themes, and 377 (61.40\%) with inanimate ones. Positive sentences account for $76.22 \%$ of the total (468 tokens), with the remainder comprising negative sentences (118 tokens/ 19.22\%), double-negative sentences ( 2 tokens/0.33\%), and questions ( 26 tokens/4.23\%). In terms of the verbals in the collected tokens, $260(42.35 \%)$ are monosyllabic; $308(50.16 \%)$ are compound verbals; and 46 (7.49\%) are other verbal structures such as VP, V+PP, V+VP and V+得 de + descriptive complement.

Focusing on the monosyllabic verbs in TVS, 37 of them occur in more than one token. Their type frequencies in TVS are presented in Table 5.

Table 5: Type frequencies of monosyllabic verbs in TVS in Die Satisfied

\begin{tabular}{|c|c|c|c|c|c|}
\hline Verb & Meaning & Frequency & Verb & Meaning & Frequency \\
\hline 去 & go & 22 & 吃 & eat & 2 \\
\hline 来 & come & 21 & 出 & exist & 2 \\
\hline 说 & say & 15 & 倒 & collapse & 2 \\
\hline 醒 & wake up & 7 & 到 & arrive & 2 \\
\hline 开 & open & 6 & 掉 & fall & 2 \\
\hline 变 & change & 5 & 烦 & annoy & 2 \\
\hline 有 & have & 5 & 放 & put & 2 \\
\hline 动 & move & 4 & 甘 & reconcile & 2 \\
\hline 回 & return & 4 & 换 & change & 2 \\
\hline 滚 & roll & 3 & 活 & live & 2 \\
\hline 红 & red & 3 & 尽 & finish & 2 \\
\hline 见 & see & 3 & 忍 & endure & 2 \\
\hline 流 & flow & 3 & 如 & be like & 2 \\
\hline 扭 & twist & 3 & 算 & count & 2 \\
\hline 起 & rise & 3 & 锁 & lock & 2 \\
\hline 散 & disperse & 3 & 提 & bring up & 2 \\
\hline 退 & retreat & 3 & 停 & stop & 2 \\
\hline 要 & want & 3 & 粘 & stick to & 2 \\
\hline 做 & do & 3 & Total & & 212 \\
\hline
\end{tabular}

TVS tokens of Modern Mandarin structured around monosyllabic verbs are exemplified below:

(55) 我 屁股 纹丝不 动。

Wo pigu wensi bu dong.

1 butt bit NEG move

'My butt did not move a little bit.' 
(56) 我腰扭了。

Wo yao niu-le.

1 waist twist-LE

'I twisted my waist.'

(57) 我 吓了一跳。

Wo xia-le yi-tiao.

1 frighten-LE one-jump

'I was so frightened that I jumped up.'

With regard to the compound verbals seen in TVS tokens, again if represented as " $X Y$ " structures, the most frequent elements in the $\mathrm{Y}$ slot include 来 lai 'come' (in 40 tokens), 去 qu 'go' (18 tokens), 出 chu 'go out' (seven tokens), 过 guo 'pass' (six tokens), 入 $r u$ 'enter' (five tokens), 开 kai 'open; turn on' (five tokens), 完 wan 'finish' (four tokens) and 生 sheng 'grow; accrue' (three tokens). Examples are as follows:

(58) 她 的 眼泪 刷

地下来了。

Ta de yanlei shua de xia-lai-le.

3Fem DE tears 'shua' (the sound of tears) DE go down-come-LE

'Her tears suddenly fell.'

(59) 青春期穿着军装度过。

Qingchunqi chuan-zhe junzhuang du-guo.

puberty wear-ZHE military uniform spend-pass

'(His) puberty was spent wearing military uniforms.'

(60) 他的手也无力地松开。

Ta de shou ye wu li de song-kai.

3Masc DE hand also no power DE loose-open

'His hands were loosened powerlessly.'

In addition, complex verbal structures such as $\mathrm{VP}, \mathrm{V}+\mathrm{PP}$, and $\mathrm{V}+\mathrm{VP}$ are also seen in TVS, among which ' $\mathrm{V}+$ 得 $d e+$ descriptive complement' displays a considerable type frequency (seen in 19 tokens), for example:

(61) 我 的 伤口 愈合 得 不错。

Wo de shangkou yuhe de bucuo.

1 DE wound heal DE not bad

'My wound heals very well.'

(62) 事情 办 得 非常 顺利。

Shiqing ban de feichang shunli.

matter deal with DE very smoothly

'The matter is dealt with so well that it runs smoothly.' 


\subsection{Summary}

It can be noticed that TVS is extremely ancient and stable in Chinese. Besides our data, the earliest example can actually date back to oracle bone scripts:

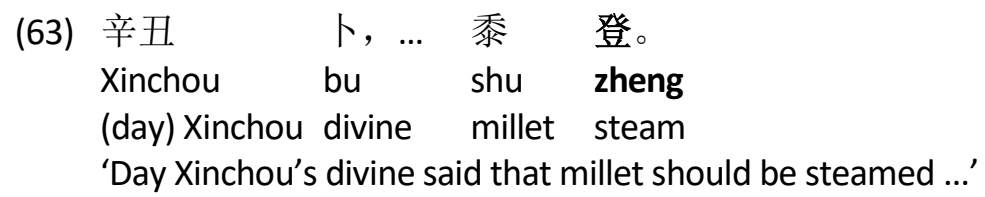

(《殷虚文字缀合》62)

The verbal semantics of the monosyllabic verbs in TVS is also very consistent. On the presented monosyllabic verb lists of different historical periods (i.e. Table 2, Table 3, Table 4 and Table 5), some verbs occur on more than one list, such as 定 ding 'pacify' (three lists), 动 dong 'break out/move' (three lists), 举 ju 'raise' (two lists), 成 cheng 'complete' (two lists), 备 bei 'prepare; ready' (two lists), 聚 ju 'accumulate' (two lists), 断 duan 'cut off' (two lists), 绝 jue 'cut off' (two lists), 毕 bi 'finish/end' (two lists), 发 $f a$ 'let off' (two lists), 下 xia 'down' (two lists), 合 he 'converge/unite' (two lists), 起 qi 'rise/ start' (two lists) and 开 kai 'open' (two lists). There are also some concepts instantiated by multiple synonyms on the lists across different historical periods, i.e., 论 $q i$, 毕 $b i$, 终 zhong, 成 cheng, 罢 $b a$, 尽 jin and 了 liao for 'finish/complete/end'; 断 duan and 绝 jue for 'cut off'; 变 bian and 化 hua for 'change'; 落 luo and 下 xia for 'fall'; 见 xian and 生 sheng for 'appear'; 聚 ju and 集 ji for 'gather/accumulate'; 空 kong and 虚 $x u$ for 'empty'. Antonyms are also seen, such as 聚 $j u$ /集 $j i$ 'gather/accumulate' and 散 san 'disperse'; 起 qi 'start' and 止 zhi 'stop'; 举 ju 'raise' and 谪 zhe 'exile'; 来 lai 'come' and 去 qu 'go'. Importantly, all the above verbs invariably denote a change of state, and other change-of-state verbs include 解 jie 'untie', 通 tong 'dredge', 销 xiao 'melt', 失 shi 'lose', 荡 dang 'swing', 飞 $f e i$ 'fly', 迷 mi 'infatuate', 明 ming 'light', 暖 nuan 'warm', 醒 xing 'wake', 愈 yu 'recover', 醉 zui 'drunk', 滚 gun 'roll', 扭 niu 'twist', 散 san 'disperse', etc.

Besides monosyllabic verbs, since Chinese has undergone a massive process of disyllabification (Arcodia, 2007; Dong, 2002), compound verbals have been dramatically gaining momentum in TVS, especially since Early Mandarin. In a widelycited work, Li \& Thompson (1981, pp. 54-72) classified Chinese verb compounds into two types - the resultative verb compound (RVC) and the parallel verb compound based on the semantic relations between their constituents. An RVC is always composed of two elements, although each element may itself be a compound. A twoelement verb compound is considered an RVC if the second element signals some result of the action or process conveyed by the first element. In a parallel verb compound, on the other hand, the two verbs are either synonymous or signal the same type of predicative notions. Based on this classification, it can be noticed that compound verbals in TVS are predominantly resultative instead of parallel. As is presented before, 
if the structure of two-element predicative compound verbals is represented as " $X Y$ ", $X$ can be various types of verbs, and the most frequent elements in the $Y$ positon include 来 lai 'come', 去 qu 'go', 得 de 'get', 出 chu 'go out', 过 guo 'pass', 入 ru 'enter', 开 kai 'open; turn on', 完 wan 'finish', etc. Remarkably, these verbal elements invariably imply a resultative state, which means the most common structure of predicative compound verbals in TVS can be represented as " $X$ - resultative state", matching the structure of RVC. As for the complex verbal structures seen in TVS, following the head verb, PP, VP or the '得 de + descriptive complement' structure typically expresses a resultative state.

To summarize, the semantic prototype of the predicates in TVS is change of state. This claim does not necessarily exclude other verbals from TVS, and indeed, there are quite a few action verbs (e.g., 说 shuo 'say', 拔 ba 'pull out', and 吃 chi 'eat') and cognition/ perception/emotion verbs (e.g., 看 kan 'look', 听 ting 'listen', 爱 ai 'love', 要 yao 'want') captured in our data. By 'semantic prototype' it is just to say change-ofstate verbs claim the lion's share of the verbals in TVS.

\section{$4 \quad$ Faithfulness of Verbs to TVS}

To select verbs for contingency analysis, factors of overall frequency, polysemy, homonym, stability of verbal semantics, and semantic diversity need to be taken into consideration. On the one hand, target verbs should ideally be frequent in language use to guarantee the applicability of this study. On the other hand, many verbs with high frequency are polysemies or homonyms. For example, the character 行 xing/hang has always been frequently used in the history of Chinese, but despite the verbal sense of 'go; implement', the original meaning of 行 $x i n g /$ hang is 'road', alongside 'line; row; army' and many other meanings. In addition, with the motive of revealing the function of TVS, any historical change of target verbs' verbal semantics will add another layer to discussion. With these factors considered, I narrowed my study down to six verbs, specifically 助 zhu 'help', 听 ting 'listen', 备 bei 'prepare', 斌 shi 'kill', 聚 ju 'accumulate', 完 wan 'finish' and 弃 $q i$ 'discard'. These six verbs present an diversity in terms of verbal semantics, with 完 wan 'finish' and 聚 ju 'accumulate' inherently encoding change of state, 备 bei 'prepare' and 弃 qi 'discard' implying change of state in certain contexts, and 助 zhu 'help' and 听 ting 'listen' not changing state whatsoever.

I searched these six target verbs in the corpora of different historical periods (i.e. the pre-Qin period for Old Chinese, the Tang dynasty for Middle Chinese, the Ming dynasty for Early Mandarin, and Modern Mandarin after 1949), and coded the tokens to identify TVS. If more than 500 tokens are attained for a historical period, only 500 tokens are coded. For each target verb of each historical period, its faithfulness to TVS is estimated by the proportion of total tokens that appear in this construction. Results are shown in Table 6. 
Table 6: Faithfulness of target verbs to TVS in different historical periods

\begin{tabular}{lrrrrr}
\hline & \multicolumn{1}{c}{ Pre-Qin } & \multicolumn{1}{c}{ Tang } & \multicolumn{1}{c}{ Ming } & Modern & \multicolumn{1}{c}{ Average } \\
\hline 助 zhu 'help' & 0.0122 & 0.0095 & 0.0020 & 0.0000 & 0.0059 \\
听 ting 'listen' & 0.1487 & 0.1434 & 0.0129 & 0.0270 & 0.0830 \\
弃 qi 'discard' & 0.1092 & 0.2542 & 0.0900 & 0.1594 & 0.1532 \\
备 bei 'prepare' & 0.2608 & 0.4483 & 0.1549 & 0.2247 & 0.2722 \\
聚 ju 'accumulate' & 0.3176 & 0.5426 & 0.4765 & 0.4403 & 0.4443 \\
完 wan 'finish' & 0.3333 & 0.5116 & 0.4146 & 0.6111 & 0.4677 \\
\hline
\end{tabular}

Note. Data presented in this table are all based on target verbs functioning independently as the predicates. Tokens are not included if target verbs serve as elements of compound verbals.

Data can be plotted in the following figure:

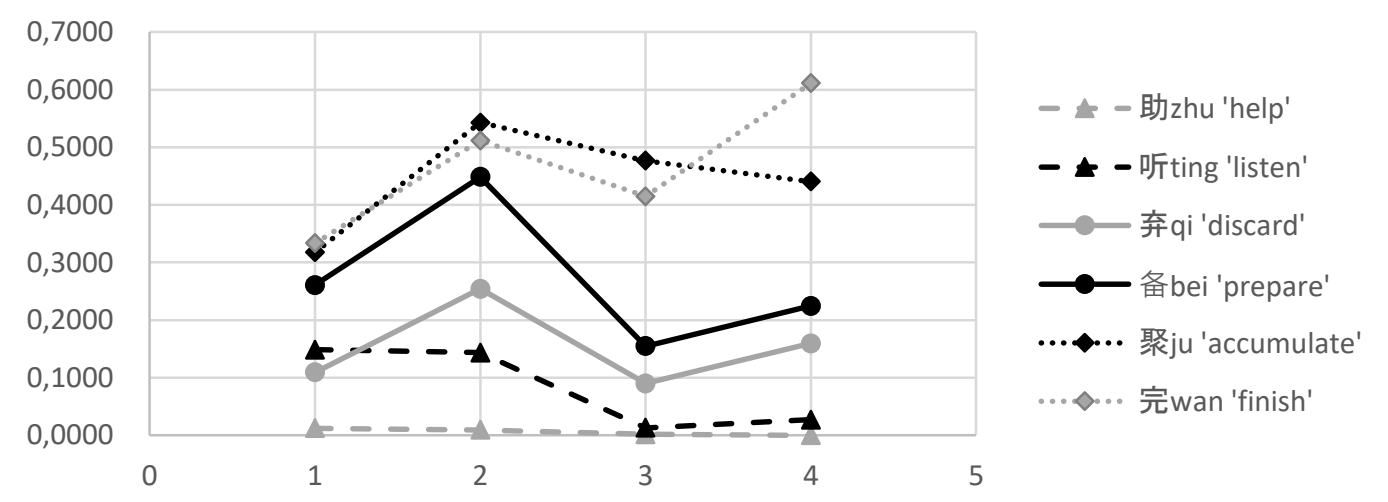

Figure 2: Faithfulness of target verbs to TVS in different historical periods

Despite the diachronic variations, the overall correlation between verbal semantics and verbs' faithfulness to TVS is clearly demonstrated. Inherent change-of-state verbs, i.e., 聚 ju 'accumulate' and 完 wan 'finish', are consistently the most faithful to TVS, followed by verbs that can imply change of state in certain contexts, such as 备 bei 'prepare' and 弃 qi 'discard'. 助 Zhu 'help' and 听 ting 'listen' are the least likely to change the state of the theme, and correspondingly, they rarely occur in TVS.

It is noteworthy that I am not trying to demarcate the boundary between changeof-state verbs and non-change-of-state verbs. Essentially, cognitive construction grammar holds a prototype view towards semantics: (Semantic) categories are not always well-delineated but structured around prototypes, with degrees of membership (Goldberg, 1995, pp. 13-14; Langacker, 2008, p. 13). In this discussion, the transition from change of state to non-change of state is better perceived as a continuum, which is, as can be observed from Figure 2, also reflected in verbs' faithfulness to TVS. 


\section{$5 \quad$ TVS and NPC}

\subsection{The change-of-state construction}

The above analysis has shown that the semantic prototype of the verbals in TVS has constantly been change of state, and change-of-state verbs are also the most faithful to TVS than other verbs. Therefore, it can be conjectured that the function of TVS is related to change of state. This conjecture is supported by some cross-linguistic findings. TVS is short for the 'theme + verbal' structure with the transitive use of the verbal also confirmed from corpus data, and thus demonstrates the phenomenon of transitivity alternation. With regard to transitivity alternation, Haspelmath (1993) extrapolated that three large classes of situations are excluded from it (he used 'inchoative/causative alternation' to refer to transitivity alternation, to be discussed in the following section):

(64) First, a state cannot be the inchoative member of an inchoative/causative alternation. Second, an action that does not express a change of state (e.g. 'help', 'invite', 'cite', 'criticize', 'read') cannot be the causative member of such an alternation. Third, agentive intransitive verbs like 'talk', 'dance', 'work', etc. cannot be the inchoative member of an inchoative/causative pair because they are not conceived of as occurring spontaneously. This still leaves us with a large class of transitive verbs such as 'wash', 'build', 'cut', 'dig', 'paint', etc., which do express a change of state. (Haspelmath, 1993)

This opinion coincides with the causal approach to lexical semantics (cf. Croft, 1991; Leven \& Rappaport Hovav, 2005), which was introduced to account for transitivity alternation in English. According to Levin \& Rappaport Hovav (2005, p. 117), the causal approach to lexical semantics "takes the facets of verb meaning relevant to argument realization to involve the causal structure of the events denoted". Tsunoda's (1981, 1985) simplified hierarchy, which originally organized the semantic classes of two-place verbs according to the likelihood of their members' transitivity, was adopted by Levin (2009) in the following form:

(65) Change of state > Surface contact > Perception/cognition

As shown in example (35), below, change-of-state verbs (including change-oflocation verbs) are perceived as inherently causative, and identify force recipients; whereas surface-contact verbs (including exertion-of-force verbs) identify force recipients, but do not entail changes of state. Perception/cognition verbs, meanwhile, involve neither force recipients nor changes of state.

(66) Change-of-state verbs: break, open, close, warm, dim, cool, flatten, ...

Surface-contact verbs: hit, kick, shoot, slap, beat, wipe, rub, scratch, sweep, ...

Perception/cognition verbs: hear, see, smell, know, enjoy, fear, hate, ... 
Citing Croft (1991, 1994, 1998), DeLancey (1984), Langacker (1987) and Talmy (1976), Levin (2009) concluded that "one instantiation of the causal approach models events in terms of individuals acting on individuals, thus involving causal chains, consisting of a series of segments (or 'atomic events'), each relating two participants in the event" and that "a single participant may be involved in more than one segment". It should be noted that change-of-state verbs encode this causal chain by definition. The transitive form of 'break' has been used as an example to illustrate the causal chain, as follows:

(67) Harry broke the vase. Modelled with a three-segment causal chain:

(i) Harry acts on the vase

(ii) the vase changes state

(iii) the vase is in a result state (i.e., broken)

(Croft, 1994, p. 38)

Complex event structures can be observed for this kind of verbs.

(68) break: [ [ $\mathrm{xACT}]$ CAUSE [ BECOME [ $y<B R O K E N>]]]$

(Levin \& Rappaport Hovav, 2005, p. 113)

Connecting the findings about transitivity alternation in Chinese with other languages, a cross-linguistic change-of-state construction can be proposed for the form TVS:

Table 7: The architecture of the change-of-state construction

\begin{tabular}{lll}
\hline Form & $\begin{array}{l}\text { theme + verbal } \\
\text { Constituents }\end{array}$ & $\begin{array}{l}\text { theme: prototypically inanimate } \\
\text { verbal: prototypically encoding change of state } \\
\text { prototypically in the perfective aspect }\end{array}$ \\
Function & $\begin{array}{l}\text { Constraints } \\
\text { Change of state }\end{array}$ & \\
\hline
\end{tabular}

\subsection{The factor of spontaneity}

Given the recognition of the change-of-state construction (taking the form of TVS, analyzed from corpus data), a question arises as to whether it can be equated with NPC. As is mentioned in the beginning, the form of NPC is not clearly defined except for "no overt passive marker", and it is still open to question whether the following TVS can be treated as NPC. Examples (3)-(6) are repeated as (38)-(41) for the reader's convenience.

(69) 物 以 类聚。 thing by category accumulate

'Things accumulate by category.' 
(70) 电影完了。

Dianying wan-le

movie finish-LE

'The movie finished.'

(71) 门 开了。

Men kai-le.

door open-LE

'The door opened./ The door is opened.'

(72) 蛋糕 吃了

Dangao chi-le.

cake eat-LE

'The cake is eaten.'

In previous studies, (41) is undoubtedly cited as an example of NPC and (40) is occasionally also treated as NPC, but (38) and (39) are clearly not discussed. As for what is the difference between them, relevant discussions are seen from Haspelmath (1987) and Huang (1989). They both hold that there must be an implied agent in passive, as explained in the following quote:

(73) In the passive, the actor is not in the subject position, but it can often be expressed in an actor phrase, and in any case the existence of an actor is implied in a passive clause. In the anticausative, however, the actor is completely eliminated, not only syntactically, but also semantically. And the process is presented as going on spontaneously. This semantic distinction is often quite subtle, but it is decisive. (Haspelmath, 1987)

Based on this principle, it can be extrapolated that NPC is the TVS wherein lies an applied agent, and if there is not, the TVS is called anticaustive ${ }^{1}$, indicating the process occurs spontaneously. In the discussion of the famous Chinese ambiguous sentence 鸡 不吃了 ji bu chi-le 'the chick will not be eaten', Huang (1989) used exactly the same standard to exclude this example from ergative. This opinion is primarily based on verbal semantics. Indeed, the action 'eat' involves two participants of the event. However, out of context, both interpretations are possible for (40): the door may open itself or be opened by somebody else. Essentially, the events expressed by many words allow both possibilities, and the spontaneity of verbal semantics is not binary. Nedjalkov \& Sil'nickij (1969/1973) presented the following scale of spontaneity in their discussion of inchoative/causative alternations, which was later reaffirmed by Haspelmath (1993):

\footnotetext{
${ }^{1}$ In studies of Chinese linguistics, probably due to the lack of inflectional morphology, the use of the term "anticausative" has been extensively mingled together with "ergative", "unaccusative" and "inchoative", despite their distinct origins.
} 
(74) Scale of increasing likelihood of spontaneous occurrence

\begin{tabular}{c|c|l} 
'wash' & 'close' 'melt' & 'laugh' \\
& inchoative/causative alternations &
\end{tabular}

(Nedjalkov \& Sil'nickij, 1969/1973; Haspelmath, 1993)

Zooming in on the section that can participate in inchoative/causative alternations (change-of-state events), Haspelmath (1993) expanded the scope of this analysis and thus derived a scale with more nodes. Selected nodes are presented below in Figure 3, in conjunction with the distinction of change/non-change of state discussed in the prior section.

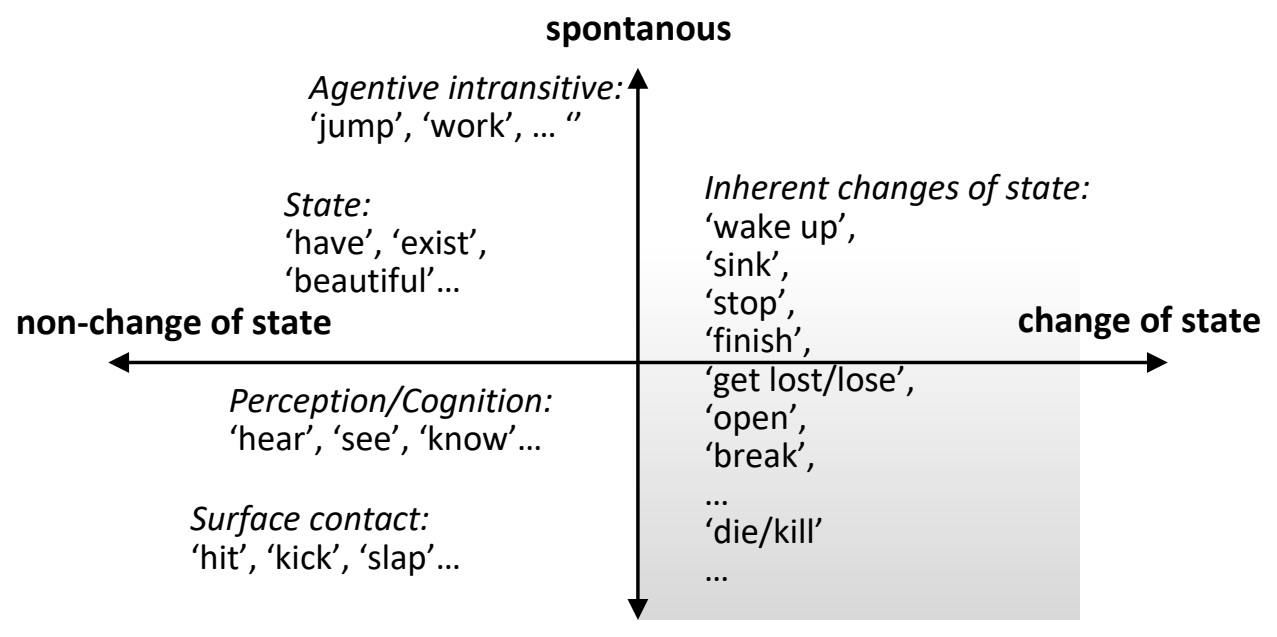

caused/affected by external force

Figure 3: Four types of events based on two factors

If NPC is understood to be the TVS containing an implied agent, then the grey area covers the events expressed by NPC. The darker the grey is, the less likely the event is to occur spontaneously, and thus better fits the defined characteristic of passive, i.e., there is an agent. In this sense, NPC refers to a special situation of the change-of-state construction when the event expressed by the verbal semantics is not likely to occur spontaneously. This explains why example (41) sounds more like passive than (40).

In many languages including English, events represented in the dark grey area cannot be expressed by TVS without a passive marker. Haspelmath $(1987,1993)$ noted the contrast between English verbs 'cut' and 'tear' to demonstrate that concepts of actions involving agent-oriented meaning components, such as tools or methods, virtually never alternate between transitive and intransitive use. The situation is obviously different in Chinese as in corpus data, we have seen quite a few action verbs, including 说 shuo 'say', 拔 $b a$ 'pull out', and 吃 chi 'eat', in TVS tokens. It is this 
difference that makes NPC a special phenomenon and the distinction between NPC and inchoative/unaccusative/ergative/anticausative a special problem in Chinese. If verbs involving agent-oriented meaning components cannot form TVS whatsoever, there will definitely not be an implied agent, and thus TVS cannot be called 'passive'. But as in Chinese, the verbals in TVS may involve agent-oriented meaning components or not, and the likelihood of spontaneous occurrence encoded in verbal semantics is a continuous scale instead of binary, there is essentially no way to tear apart NPC and inchoative/ unaccusative/ergative/anticausative.

\subsection{The cognitive base the change-of-state construction}

As previously discussed, cognitive construction grammar is built upon the relationship between linguistic constructions and human cognition, explicated below in the Scene Encoding Hypothesis (Goldberg, 2005).

(75) Scene Encoding Hypothesis: Constructions which correspond to basic sentence types encode as their central senses event types that are basic to human experience. (Goldberg, 2005)

In light of this basic tenet of cognitive construction grammar, the event expressed by the change-of-state construction can be represented by the following diagram, in which ' $A G$ ' signifies agent, and ' $T H$ ', theme:

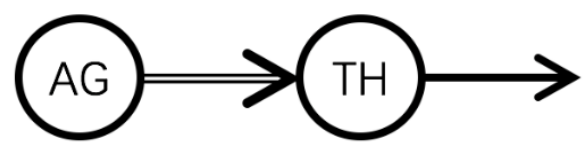

Figure 4: The complex event structure of change-of-state verbs

This complex event structure automatically gives way to two competing strategies of profiling in human construal: agent orientation and theme orientation. According to Langacker (2008, p. 355), since it is difficult to attend to a complex occurrence in a global and wholly neutral fashion, attention, as a limited resource, has to be allocated. As a matter of focal prominence, trajector and landmark are the primary and secondary focal participants in a profiled relationship, and subject/object relations are grammatical manifestations of trajector/landmark alignment. A subject is a nominal that codes the trajector of a profiled relationship, and an object is one that codes the landmark. It should be noted, however, that (i) different allocations are possible for a given structure, and (ii) the choice of trajector is a pivotal factor in canonical alignment. The key difference between the two major profiling strategies is that one aligns the trajector with the agent, and the other aligns it with the theme.

(76) Agent and theme attract focal prominence because each has a kind of cognitive salience that sets it apart from other semantic roles in its experiential realm. Agents belong to the "active" realm - that of action, change, and force, of mobile 
creatures acting on the world. Here a willful human actor stands out as a paragon with respect to other active roles (like instrument, experiencer, or natural force). On the other hand, themes belong to the "passive" realm of settings, locations, and stable situations, where objects with particular properties are arranged in certain ways. The world thus constituted defines our circumstances, presents both problems and opportunities, and serves as the platform for human activity.

(Langacker, 2008, p. 370)

In the complex event structure of a change of state, both participants have a chance of being profiled as the trajector, which means that each of them can be the subject of a clause: transitivity alternation is thus made possible.

A fundamental spirit underlying this view is that the same event can be profiled in different ways and further realized as distinct constructions in language. Bearing this in mind, it becomes questionable that whether the "notional passive construction" is passive at all. Even if we acknowledge that NPC refers to the change-of-state constructions in which the event expressed by verbal semantics is not likely to occur spontaneously, the actual conceptualization of this event may be a different story: involving an agent-oriented meaning component in verbal semantics does not mean this event is necessarily profiled so when realized in language. An alternative possibility certainly exists that the agent is simply not attended to when we use TVS. If so, this TVS can no longer be treated as "passive" according to the standard of the "implied agent".

\subsection{Summary: the challenges of the idea of "notional passive"}

TVS, as the form designated by NPC, inherently hinges on change of state. Taken as the change-of-state construction, our finding about TVS can be situated in a cross-linguistic context. The recognition of the cross-linguistic change-of-state construction casts doubt on NPC's status as a construction. Under the view of cognitive construction grammar, a construction is defined as a pairing of form and function, but in the case of NPC, the real function of its form is change of state. If a transitive verb does not encode change of state, e.g., 助 zhu 'help', it seldom occurs in TVS. Therefore, NPC can only be understood as a special situation of the change-of-state construction in which the event expressed by the verbal is not likely to occur spontaneously. In this sense, the use of the term 'construction' is groundless in the so-called "notional passive construction".

Moreover, from the perspective of verbal semantics, events' likelihood of spontaneous occurrence is not binary but falls on a continuum, making it impossible to distinguish NPC (which is argued to imply an agent) from inchoative/unaccusative/ ergative/anticausative (which is understood to happen spontaneously) in Chinese.

Most importantly, within the framework of cognitive construction grammar, the event itself cannot be equated with human conceptualization of it encoded in 
constructions, because one event can be profiled in multiple ways. Therefore, even if the event expressed by verbal semantics is not likely to occur spontaneously, we still do not know whether an agent is implied when we use this verbal in the change-ofstate construction. In this sense, the use of the term "passive" is rather arbitrary in the so-called "notional passive construction", albeit plausible.

\section{Conclusions and future directions}

With the motive of revealing the form, function and conceptual schema of the notional passive construction under the framework of cognitive construction grammar, this study employs a diachronic character-based approach to investigate the theme + verbal' structure in corpus data. Results show that the semantic prototype of the verbal in the 'theme + verbal' structure is change of state, and change-of-state verbs are also the most faithful to this structure. In conjunction with the finding about transitivity alternation in other languages, a change-of-state construction can be proposed. With the use the terms "passive" and "construction" questionable, the so-called "notional passive construction" virtually refers to a special situation of the change-of-state construction in which the event expressed by verbal semantics is not likely to occur spontaneously.

That being said, how could the concept "notional passive construction" emerge and become commonly used in Chinese linguistics? A possible reason pertains to the difference between Chinese and other languages discussed at the end of section 5.2. In many languages, verbs involving agent-oriented meaning components cannot be used intransitively without a passive marker, but that is possible in Chinese, making some Chinese change-of-state constructions not translatable in other languages without a passive marker. If this is the case, the idea of "notional passive construction" is the outcome of an attempt trying to align Chinese with other languages, and the distinction between the notional passive construction and inchoative/ unaccusative/ ergative/anticausative is radically meaningless because these notions are originally imposed on Chinese.

Last but not least, there are a few points that call for further discussion. First, in the diachronic analysis, this paper focuses pretty much merely on the consistency across different historical periods, but we do see considerable diachronic variations, especially with the increasing occurrence of verb compounds and compound verbs. So, it is of interest to see the interrelationship between compounding and the evolution of the verbals in the change-of-state construction. Second, although currently we do not know whether an agent is implied when we use the change-of-state construction, it can probably be found out through experiments testing native speakers' online processing. This is certainly worth doing since semantically, the verbal in the Chinese change-of-state construction may involve agent-oriented components, which entails a 
potential existence of an implied agent in the Chinese change-of-state construction. Third, as is mentioned in the beginning of this paper, besides the "notional passive", Chinese does have a commonly recognized passive marker, 被 bei. If the idea of "notional passive construction" is dubious, how about the 被 bei construction? What is the relationship between them? These are all questions worthy of exploration.

\section{References}

Arcodia, G. (2007). Chinese: A language of compound words? In F. Montermini, G. Boyé, \& N. Hathout (Eds.), Selected proceedings of the 5th Décembrettes: Morphology in Toulouse (pp. 79-90). Somerville, MA: Cascadilla Proceedings Project.

Baxter, W. H., \& Sagart, L. (1998). Word Formation in Old Chinese. In J. L. Packard (Eds.), New approaches to Chinese word formation (pp. 35-75). Berlin-New York: Mouton de Gruyter.

Boas, H. C. (2013). Cognitive Construction Grammar. In T. Hoffmann \& G. Trousdale (Eds.), The Oxford Handbook of Construction Grammar (pp. 233-254). Oxford: Oxford University Press.

Bybee, J. L. (2010). Language, Usage, and Cognition. Cambridge: Cambridge University Press.

Bybee, J. L. (2012). Usage-based theory and exemplar representations of construction. In T. Hoffmann \& T. Graeme (Eds.), The Oxford handbook of construction grammar (pp. 49-69). New York: Oxford University Press. Retrieved from https://www.unm.edu/ jbybee/downloads/Bybee2013UBTandExRep.pdf

Cheng, L. L.-S., \& Huang, C.-T. J. (1994). On the argument structure of resultative compounds. In M. Chen \& O. Tzeng (Eds.), In honor of William Wang: Interdisplinary studies on language and language change (pp. 187-221). Taipei: Pyramid Press.

Cheung, H.-n., Liu, S.-y., \& Shih, L.-I. (1994). A practical Chinese grammar. Hong Kong: The Chinese University Press.

Croft, W. (1991). Syntactic categories and grammatical relations. Chicago, IL: University of Chicago Press.

Croft, W. (1994). The semantics of subjecthood. In M. Yaguello (Ed.), Subjecthood and subjectivity (pp. 29-75). Paris: Ophrys.

Croft, W. (1998). Event structure in argument linking. In M. Butt \& W. Geuder (Ed.), The projection of arguments: lexical and compositional factors (pp. 21-63). Stanford, CA: CSLI Publications.

Croft, W. (2001). Radical construction grammar. Oxford: Oxford University Press.

Croft, W. (2012). Verbs: Aspect and causal structure. Oxford, UK: Oxford University Press.

DeLancey, S. (1984). Notes on agentivity and causation. Studies in Language, 8, 181-213.

Dong, X. (2002). Cihuihua: Hanyu shuangyinci de yansheng he fazhan 词汇化：汉语双音词的 衍生和发展 [Lexicalization: The emergence and development of Chinese disyllabic words]. Chengdu: Sichuan Nationalities Publishing House.

Ellis, N. C., \& O'Donnell, M. B. (2011). Robust Language Acquisition-an Emergent Consequence of Language as a Complex Adaptive System. In L. Carlson, C. Hölscher \& T. Shipley (Eds.), Proceedings of the 33rd Annual Conference of the Cognitive Science Society (pp. 3512-3517). Austin, TX: Cognitive Science Society. 
Ellis, N. C., \& Cadierno, T. (2009). Constructing a second language. Introduction to the Special Section. Annual Review of Cognitive Linguistics, 7, 111-139.

Ellis, N. C., O’Donnell, M., \& Römer, U. (2014). Second Language Verb-Argument Constructions are Sensitive to Form, Function, Frequency, Contingency, and Prototypicality. Linguistic Approaches to Bilingualism, 4(4), 405-431. Secondlanguageconstructions_LAB\#2 preprint.pdf

Ellis, N. C., O’Donnell, M. \& Römer, U. (2015). Usage-based language learning. In B. MacWhinney \& W. O'Grady (Eds.), The handbook of language emergence (pp. 163-180). Hoboken: Wiley-Blackwell.

Goldberg, A. E., Casenhiser, D. M., \& Sethuraman, N. (2004). Learning argument structure generalizations. Cognitive Linguistics, 15, 289-316.

Goldberg, A. (1995). Constructions: A construction grammar approach to argument structure. Chicago: University of Chicago Press.

Goldberg, A. (2003). Constructions: A new theoretical approach to language. Trends in Cognitive Science, 7, 219-224.

Goldberg, A. (2006). Constructions at work. Oxford: Oxford University Press.

Haspelmath, M. (1987). Transitivity alternations of the anticausative type. Arbeitspapier 5. Institut für Srachwissenschaft, Universität zu Köln, 1-51.

Haspelmath, M. (1993). More on the typology of inchoative/causative verb alternations. In B. Comrie \& M. Polinsky (Eds.), Causatives and transitivity (pp. 87-120). Amsterdam \& Philadelphia: John Benjamins.

Huang, C.-T. J. (1989). Zhongwen de liangzhong jiwu dongci he liangzhong bujiwu dongci 中文 的两种及物动词和两种不及物动词 [Two kinds of transitive verbs and intransitive verbs in Chinese], In Proceedings of the 2nd World Congress of Chinese Language Studies (pp. 3959). Taipei: World Chinese Language Association.

Keenan, E. L. (1985). Passive in the world's languages. In T. Shopen (Ed.), Language typology and syntactic description, Vol. 1: Clause Structure (pp. 243-281). Cambridge: Cambridge University Press.

Langacker, R. W. (1987). Foundations of cognitive grammar, vol. 1. Stanford: Stanford University Press.

Langacker, R. W. (1988). A usage-based model. In B. Rudzka-Ostyn (Ed.), Topics in cognitive linguistics (pp. 27-161). Amsterdam and Philadelphia: John Benjamins.

Langacker, R. (2008). Cognitive grammar: A basic introduction. New York: Oxford University Press.

Levin, B., \& Rappaport Hovav, M. (2005). Argument Realization. Cambridge, UK: Cambridge University Press.

Levin, B. (1993). English verb classes and alternations. Chicago: University Press of Chicago.

Levin, B. (2009). Lexical semantics of verbs III: causal approaches to lexical semantic representation. Course LSA 116, UC Berkeley. Retrieved from http://web.stanford.edu/ bclevin/lsa09causapp.pdf

Li, C. N., \& Thompson, S. A. (1981). Mandarin Chinese: A functional reference grammar. Berkeley: University of California Press. 
Li, Y.-c. (1994). Hanyu zhuti yu zhuyu zhi bian 汉语主题与主语之辩 [The distinction between topic and subject in Chinese]. In Disanjie shijie huayuwen jiaoxue yantaohui lunwenji lilun yu fenxi pian (shangce) 第三届世界华语文教学研讨会论文集理论与分析篇（上册） [Proceeding of 3th Conference of World Chinese Language Association: Theory and analysis] Vol. 1. (pp. 19-28). Taipei: World Chinese Press.

McEnery, T., \& Xiao R. (2010). Corpus-based contrastive studies of English and Chinese. London: Routledge.

Mei, T.-L. (1991). Cong handai de "dong, sha", "dong, si" lai kan dongbujiegou de fazhan: Jianlun Zhonggu shiqi qici de shishouguanxi de zhonglihua 从汉代的“动, 杀”, “动, 死”来看动 补结构的发展——兼论中古时期起词的施受关系的中立化 [On the development of resultative verb compound from the "verb + kill" and "verb + die" structures in Han Dynasty: Also on the neutraralization of the thematic roles of inchoative verbs in Middle Chinese]. Yuyanxue Luncong [Essays on Linguistics], 16, 112-136.

Nedjalkov, V. P., \& Jaxontov, S. E. (1983). Tipologiya rezul'tativnyx konstrukcij [Typology of resultative constructions]. In Vladimir P. Nedjalkov (Ed.), Tipologiya rezul'tativnys konstrukcij. (rezul'tativ, stative, passiv, perfekt) [Typology of resultative constructions (resultative, stative, passive, perfective)] (pp. 5-41). Leningrad: Nauka.

Ninio, A. (1999). Pathbreaking verbs in syntactic development and the question of prototypical transitivity. Journal of Child Language 26, 619-653.

Saussure, F. D. (1916/1959). In C. Bally \& A. Sechehaye (Eds.), Course in general linguistics. New York: The Philosophical Library, INC.

Talmy, L. (1976). Semantic causative types. In M. Shibatani (Ed.), Syntax and semantics 6: the grammar of causative constructions (pp. 43-116). New York: Academic Press.

Ting, J. (2006). The middle construction in Mandarin Chinese and the presyntactic approach. Concentric: Studies in Linguistics, 32(1), 89-117.

Tsunoda, T. (1981). Split case-marking patterns in verb-types and tense/aspect/mood. Linguistics, 19, 389-438.

Tsunoda, T. (1985). Remarks on Transitivity. Journal of Linguistics, 21, 385-396.

Tyler, A. (2012). Cognitive linguistics and second language learning-theoretical basics and experimental evidence. New York and London: Tayllor \& Francis Group.

Wang, C. (1998). Wubiaoji beidongju he dongci de lei 无标记被动句和动词的类 [The unmarked passive sentence and verb classes]. Hanyu xuexi 汉语学习 [Chinese Language Learning], 5, 15-19.

Wang, L. (1957). Hanyu beidongshi de fazhan 汉语被动式的发展 [The development of the bei construction]. Yuyanxue Luncong, 1, 1-16.

Wang, L. (1958/2004). Hanyu shi gao 汉语史稿 [History of Mandarin]. Beijing: Zhonghua Chubanshe.

Wang, Z. (2004). Beidong biaoshu dui zizhu dongci he feizizhu dongci de xuanze 被动表述对自 主动词和非自主动词的选择 [Selection of volitional and nonvolitional verb in passive statement]. Hanyu xuexi 汉语学习[Chinese Language Learning], 6, 17-22. 
Xu, H. (1997). Sanyinjie yuci danwei shuolve: Jianlun xiandai hanyu cihui zhong de yinjie zoushi he 'sanyinhua' qingxiang 三音节语词单位说略——兼论现代汉语词汇中的音节走势和 “三音化” 倾向 [A brief introduction to three-syllable word: Also on the development of Chinese words toward three syllables]. Shandong Ligong Daxue Xuebao 山东理工大学学 报 [Journal of Shandong University of Technology], (3), 70-74.

Yip, P.-C., \& Rimmington, D. (2004). Chinese: A comprehensive grammar. New York, NY: Routledge.

Yu, Z. (1984). Lun guhanyu buyu de yiwei 论古汉语补语的移位 [On the displacement of complements in Classical Chinese]. Yuyan Yanjiu 语言研究 [Studies in Language and Linguistics], 6(1), 104-113.

Zhou, H., \& Jin, H. (2004). Ying-Han beidongju de shiyong xianzhi 英汉被动句的使用限制 [Comparison of passive voice between English and Chinese]. Xiaogan daxue xuebao 孝感 大学学报 [Journal of Xiaogan University], 24(1), 59-61. 